\title{
Plasma prolactin concentrations during the ovarian cycle and lactation and their relationship to return of fertility post partum in the common marmoset (Callithrix jacchus)
}

\author{
A. S. McNeilly, D. H. Abbott*, S. F. Lunn, P. C. Chambers and \\ J. P. Hearn $\dagger$
}

M.R.C. Unit of Reproductive Biology, Centre for Reproductive Biology, 37 Chalmers Street, Edinburgh EH3 $9 E W, U . K$.

\begin{abstract}
Summary. A heterologous double-antibody radioimmunoassay was used to measure plasma prolactin concentrations in 27 marmosets. The assay was valid for the marmoset because plasma levels of prolactin were increased in response to TRH and metoclopramide and suppressed in response to bromocriptine treatment.

During the cycle there were no consistent changes in plasma prolactin concentrations. During lactation mothers suckling single or twin infants had higher prolactin levels than did non-suckling females and levels were highest with twins. No statistically significant delay in the resumption of ovulation post partum was observed for the suckling and non-suckling females; conception occurred in all but one marmoset by 70 days post partum.

These results show that neither the suckling stimulus nor high levels of prolactin post partum delay the return of ovulation and fertility in the common marmoset, a result in contrast to that for all other primate species so far investigated.
\end{abstract}

\section{Introduction}

Lactation in women is associated with amenorrhoea and infertility (see McNeilly, 1979, for references). Both the suckling stimulus and high levels of prolactin associated with lactation have been implicated as causal agents, but which of these two components is the more important has yet to be resolved. Lactation is also associated with a period of infertility in other primates, e.g. the rhesus monkey (Weiss et al., 1973), Savannah baboon (Attmann, Attmann \& Hausfater, 1978), chimpanzee (Tutin, 1980) and gorilla (Harcourt, Fossey, Stewart \& Watts, 1980). In contrast, lactation in the common marmoset monkey is not associated with any apparent post-partum infertility, in spite of continued sucking by the infant and its complete dependence on maternal milk for up to 100 days (Lunn \& Hearn, 1978; Chambers \& Hearn, 1979; Lunn \& McNeilly, 1981). We have therefore validated a heterologous radioimmunoassay for prolactin in the marmoset and studied the changes in plasma prolactin concentrations during the ovarian cycle (approximately 17 days) and lactation.

\footnotetext{
* Present address: Wisconsin Regional Primate Research Centre, 1223 Capitol Court, Madison, Wisconsin 53706, U.S.A.

† Present address: Institute of Zoology, Zoological Society of London, Regent's Park, London NW1 4RY, U.K.
} 


\section{Materials and Methods}

\section{Animals}

The 27 marmoset monkeys used (285-360 g body wt) were sexually mature. Full details of their management have been published previously (Hearn, Lunn, Burden \& Pilcher, 1975). Animals were exposed to natural light with additional illumination between 06:00 and 19:00 h.

\section{Experimental procedures}

To assess the changes in plasma levels of prolactin during the ovarian cycle, 10 cyclic female marmosets housed individually with vasectomized males were bled $(0.5 \mathrm{ml})$ every $3 \mathrm{rd}$ day for 30 days. Normal ovarian cyclicity was determined by measurement of the levels of progesterone in the same samples (Hearn \& Lunn, 1975).

During pregnancy and lactation, 13 marmosets were bled $(0.5 \mathrm{ml})$ between 1 and 14 days before the expected date of delivery and then every 3 or 4 days up to 90 days post partum. After parturition mothers and their surviving infants remained in the mother's peer group (Abbott \& Hearn, 1978).

To obtain blood samples the animals were held in a restraining device (Hearn, 1977), and blood samples were taken between 09:00 and 12:00 $\mathrm{h}$ without anaesthesia from the femoral vein with a heparinized syringe and placed on ice. The blood was centrifuged in the syringe barrel at $500 \mathrm{~g}$ for $20 \mathrm{~min}$ at $4^{\circ} \mathrm{C}$ and the plasma samples were stored at $-20^{\circ} \mathrm{C}$ until assayed for prolactin.

\section{Measurement of prolactin}

Marmoset prolactin was measured by a heterologous double-antibody radioimmunoassay described in detail previously (McNeilly \& Friesen, 1978). The assay uses a guinea-pig anti-human prolactin antiserum (No. 33-9) with ${ }^{125}$ I-labelled ovine prolactin as tracer and ovine prolactin (NIH-P-S6, 26 i.u./mg) as standard.

Specificity. Previous studies with a wide range of hormones from several species had shown this assay to be specific for prolactin (McNeilly \& Friesen, 1978). Since no purified marmoset prolactin standard was available, the parallelism between the ovine standard used, dilutions of marmoset plasma and a crude extract of marmoset pituitary was assessed. The pituitary extract was prepared by homogenization of 4 pituitaries $(25 \mathrm{mg})$ in $2 \mathrm{ml} 0.01 \mathrm{M}$-ammonium bicarbonate, $\mathrm{pH} 9 \cdot 0$. After shaking for $30 \mathrm{~min}$ at room temperature the extract was centrifuged at $600 \mathrm{~g}$ for $1 \mathrm{~h}$ at $4^{\circ} \mathrm{C}$ and the supernatant stored at $-20^{\circ} \mathrm{C}$ until assayed.

Accuracy and precision. Accuracy of the assay was assessed by measurement of known amounts of ovine prolactin standard $(0.3-200 \mathrm{ng} / \mathrm{ml})$ or diluted marmoset pituitary extract $(1: 5$ to $1: 1000$ ) added to marmoset plasma containing low levels of prolactin (samples taken after treatment with bromocriptine (CB154: Sandoz, Basle, Switzerland)). The precision of the assay, expressed as the intra- and inter-assay coefficient of variation (\%), was assessed by repeated assays of three pools of plasma containing 4,25 and $45 \mathrm{ng}$ prolactin/ml (approximately 80,40 and $25 \% \mathrm{~B} / \mathrm{Bo}$ ).

Biological validation. To provide biological validation of the assay, marmosets were treated with agents known to raise (thyrotrophin releasing hormone (TRH: Hoechst AG, Frankfurt, Germany) and metoclopramide (Maxalon: Beechams, Betchworth, Surrey)) or lower (bromocriptine) prolactin levels in other species. To evaluate cross-reaction with LH and FSH marmosets were also treated with LH-RH (Hoechst AG, Frankfurt, Germany).

Five cyclic female marmosets were injected with saline $(9 \mathrm{~g} \mathrm{NaCl} / 1,0.5 \mathrm{ml}$ i.v.), bromocriptine $(2.5 \mathrm{mg}$, i.m.), metoclopramide $(2.0 \mathrm{mg}$, i.m.), TRH $(25 \mu \mathrm{g}$, i.v.) or LH-RH (2 $\mu \mathrm{g}$, i.v.). Blood samples were withdrawn as described below $30 \mathrm{~min}$ before and at $0,30,60$ and $90 \mathrm{~min}$ after injection; plasma was separated and stored at $-20^{\circ} \mathrm{C}$ until assayed for prolactin. 


\section{Measurement of progesterone}

Plasma progesterone was measured by a specific radioimmunoassay exactly as previously described in detail and validated for the marmoset (Chambers \& Hearn, 1979). The sensitivity of the assay, defined as the mass of hormone required to suppress the binding of the labelled hormone to $90 \%$ of the binding achieved with no hormone added (B/Bo), was $1.7 \mathrm{ng} / \mathrm{ml}$. The mean ( \pm s.d.) recovery of labelled progesterone from plasma samples was $69 \pm 3 \%(n=95)$ and was used to correct for procedural losses during the extraction procedure. Intra- and inter-assay coefficients of variation for replicate determinations of a pool of marmoset plasma were $5 \%(n=$ $10)$ and $9 \%(n=6)$ respectively.

Statistical evaluation of results was by analysis of variance and Student's $t$ test.

\section{Results}

\section{Validation of the prolactin assay}

The comparison of inhibition curves for ovine prolactin standard and marmoset plasma and pituitary extracts are shown in Text-fig. 1. The slopes of the dose-response curves were not significantly different. Therefore all samples were assayed against, and are reported in terms of, ng ovine prolactin $/ \mathrm{ml}$ plasma.

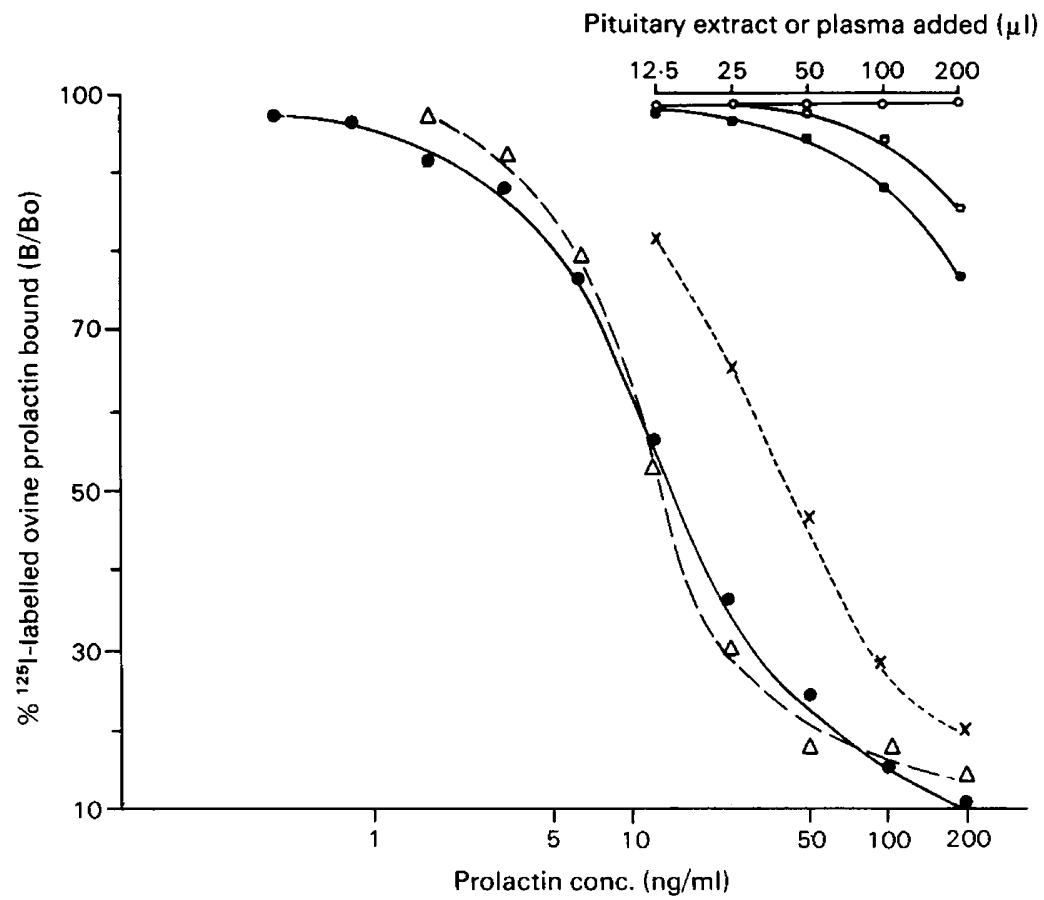

Text-fig. 1. Standard curve of ovine prolactin (e, NIH-P-S6) and dilution curves of (a) a marmoset pituitary extract $(\triangle)$; (b) plasma taken from a female marmoset after metoclopramide stimulation (X); (c) normal female marmoset plasma ( $\square$ ); (d) male marmoset plasma (D) and (e) female marmoset plasma taken after administration of bromocriptine $(\mathrm{O})$.

Accuracy and precision. The accuracy assessed by recovery of ovine prolactin standard and marmoset pituitary extract added to marmoset plasma previously assayed at $1.5 \mathrm{ng}$ prolactin $/ \mathrm{ml}$ was $97 \pm 4$ (s.e.m.) \% and $104 \pm 8 \%$ respectively $(n=4)$. The precision of the assay, as 
coefficients of variation, was $7 \%(n=16)$ and $11 \%(n=10)$ for intra- and inter-assay variation respectively.

Biological validation. As shown in Text-fig. 2, saline had no significant effect on plasma prolactin concentrations which ranged between 0.4 and $5 \mathrm{ng} / \mathrm{ml}$. The injection of bromocriptine caused suppression of plasma values to below the sensitivity of the assay (i.e. $<0.2 \mathrm{ng} / \mathrm{ml}$ compared with the preinjection value of $0.8 \pm 0.1 \mathrm{ng} / \mathrm{ml}$ ).

Both TRH and metoclopramide caused a significant $(P<0.001)$ increase in prolactin concentrations by $30 \mathrm{~min}$ after injection, the effect of metoclopramide $(32.4 \pm 3 \cdot 1 \mathrm{ng} / \mathrm{ml})$ being significantly greater $(P<0.001)$ than that of TRH $(9.7 \pm 4.3 \mathrm{ng} / \mathrm{ml})$. Injection of LH-RH had no significant effect on plasma levels of prolactin which ranged between 0.8 and $4.7 \mathrm{ng} / \mathrm{ml}$.

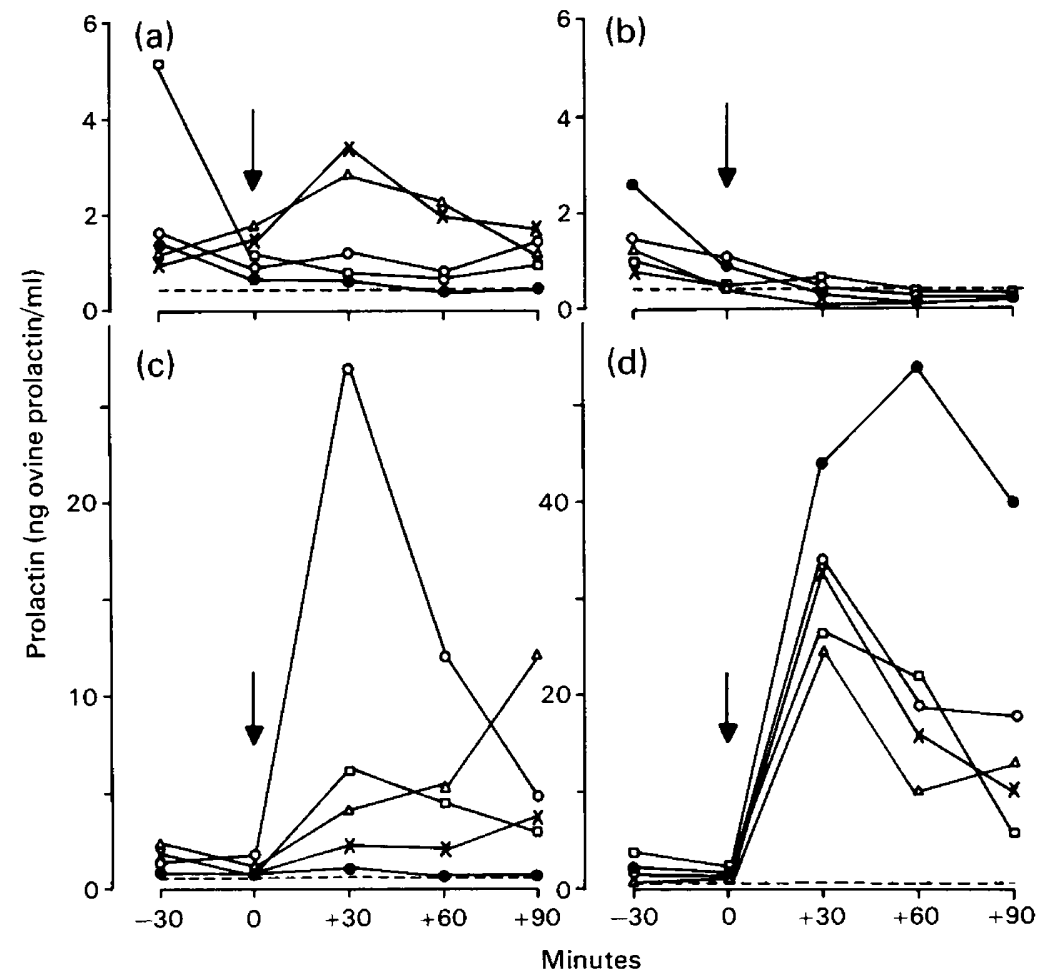

Text-fig. 2. Plasma levels of prolactin in female marmosets after the injection $(\downarrow)$ of (a) saline, (b) bromocriptine ( $2.5 \mathrm{mg}$ i.m.), (c) TRH (25 $\mu \mathrm{g}$ i.v.) or (d) metoclopramide ( $2.0 \mathrm{mg}$ i.m.). Five animals were used $(\bullet, O, \square, \triangle, x)$ and each was given all tests. The broken line indicates the sensitivity of the assay.

\section{Prolactin levels during the cycle}

The changes in plasma levels of prolactin were synchronized around the first day that plasma progesterone concentrations were $>20 \mathrm{ng} / \mathrm{ml}$ (=Day 0$)$, indicative of the start of the luteal phase (Hearn \& Lunn, 1975). No significant differences were apparent in mean levels of prolactin (Text-fig. 3a) although individual animals showed increased values in the follicular (Text-fig. 3b) and/or luteal phases of the cycle (Text-fig. 3c). 


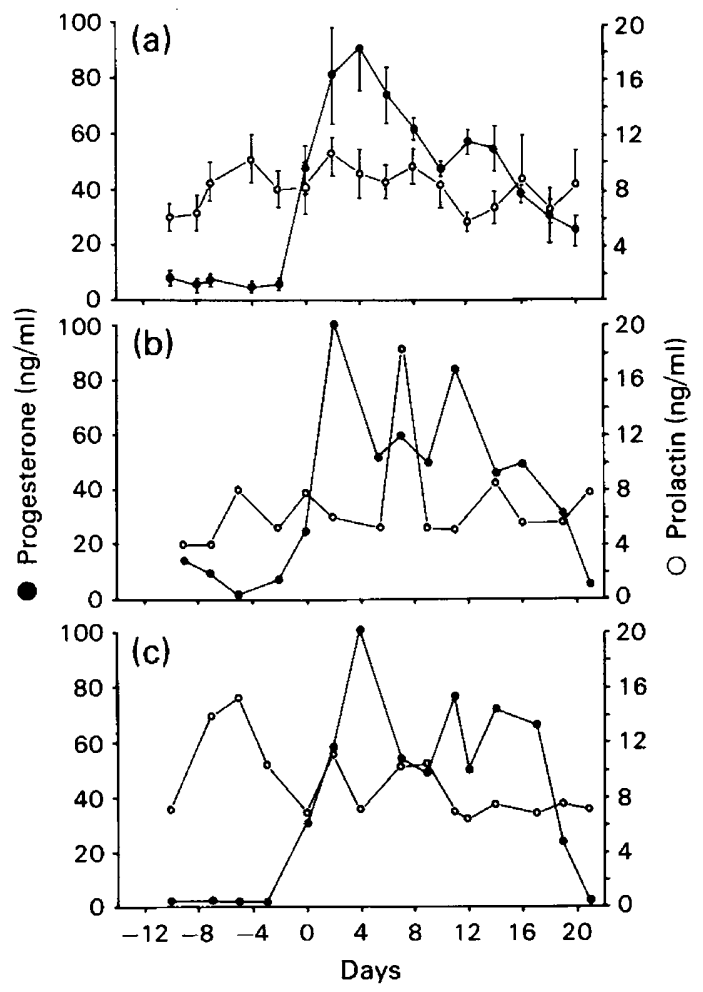

Text-fig. 3. Changes in the plasma levels (mean \pm s.e.m.) of prolactin $(O)$ and progesterone (O) during the cycle in 10 female marmoset monkeys (a) and in two individual females (b and c). The data have been synchronized around the first day progesterone values were $>20 \mathrm{ng} / \mathrm{ml}$ (Day 0 ).

\section{Prolactin levels during lactation}

Concentrations of prolactin during the last 12 days of pregnancy and during lactation are shown in Text-fig. 4. Of the 13 marmosets being bled, 5 gave birth to triplets, 7 to twins and 1 had a single infant. By Day 5 post partum all the infants of 3 mothers (one set of triplets, two sets of twins) had died, and these females were considered to be non-lactating. Two infants died

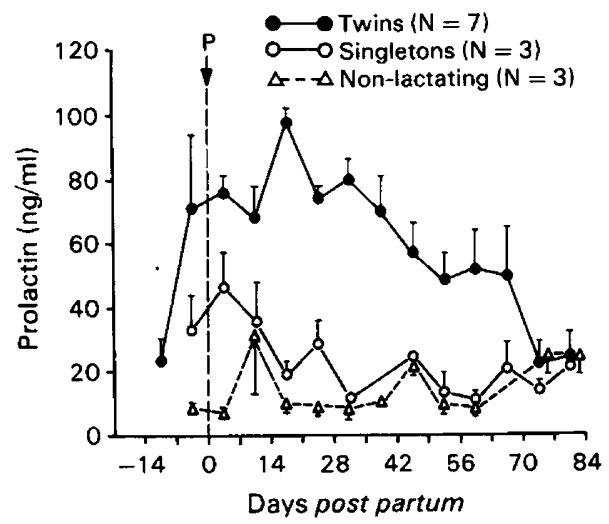

Text-fig. 4. Changes in mean \pm s.e.m. plasma prolactin concentration during lactation in marmosets suckling one $(O ; N=3)$ or two $(0 ; N=7)$ young, or not lactating $(\triangle ; N=3) . P=$ parturition. 
in each of two pairs of triplets born, leaving a group of 3 mothers with single infants. Seven mothers raised twins, two pairs of which resulted from a death in two sets of triplets. There was no relationship between the pre-partum plasma levels of prolactin and the number of young born.

In non-lactating females plasma prolactin concentrations remained low $(<22 \mathrm{ng} / \mathrm{ml})$, within the normal range for cyclic marmosets for the duration of the study (up to Days 70-77 post partum). However, between Days 8 and 14 an increase in mean plasma values occurred because of the transiently elevated prolactin levels observed in 1 of the 3 females.

Prolactin concentrations were higher in mothers suckling single infants compared to non-lactating mothers but this only achieved significance $(P<0.05)$ immediately after parturition. In contrast plasma levels of prolactin immediately post partum, and throughout lactation until around Day 65 post partum, were significantly higher $(P<0.05)$ in mothers suckling twins than in both other groups.

Ovulation followed by a rise in plasma progesterone levels occurred in all 13 animals post partum (Table 1). Plasma levels of progesterone and the duration of the luteal phase were not significantly different from those in the normal non-pregnant female.

Table 1. Days post partum to first ovulation and conception, the number of cycles to and the plasma levels of prolactin around the time of conception (Days

-7 to +7 ) in marmosets suckling no, one or two young

\begin{tabular}{|c|c|c|c|}
\hline & \multicolumn{3}{|c|}{ No. of young suckled } \\
\hline & 0 & 1 & 2 \\
\hline $\begin{array}{l}\text { Days to: } \\
\text { First ovulation } \\
\text { Conception }\end{array}$ & $\begin{array}{l}18 \pm 4(3) \\
28+8(3)\end{array}$ & $\begin{array}{l}15 \pm 1 \\
57+10(3)\end{array}$ & $\begin{array}{l}29 \pm 9(7) \\
56+11(6)\end{array}$ \\
\hline $\begin{array}{l}\text { No. of females conceiving in } \\
\text { successive cycles post partum } \\
\text { 1st } \\
\text { 2nd } \\
\text { Other }\end{array}$ & $\begin{array}{l}2 \\
1 \\
-\end{array}$ & $\begin{array}{l}0 \\
3 \\
-\end{array}$ & $\begin{array}{l}3 \\
3 \\
1^{*}\end{array}$ \\
\hline $\begin{array}{l}\text { Plasma prolactin at conception } \\
(\mathrm{ng} / \mathrm{ml})\end{array}$ & $8 \pm 1(5)$ & $23 \pm 8$ & $40 \pm 18(6)$ \\
\hline
\end{tabular}

Values are mean $t$ s.e.m. for the no. of observations in parentheses.

* Conception did not occur during the observation period.

Twelve animals became pregnant during the observation period, 5 conceiving during the first and the remainder during the second cycle post partum. The time to first ovulation assessed by progesterone levels $>20 \mathrm{ng} / \mathrm{ml}$ was not significantly different between the three groups but time of conception was significantly delayed $(P<0.05)$ in both groups of lactating mothers compared to the non-lactating females (Table 1). Prolactin concentrations around conception were also significantly higher $(P<0.05)$ in the lactating females than in those not lactating (Table 1).

\section{Discussion}

The present results for prolactin concentrations in marmosets clearly show that high levels of prolactin and a maintained suckling stimulus do not necessarily inhibit the resumption of ovarian activity and return of fertility post partum.

The application of the heterologous radioimmunoassay to the measurement of marmoset 
prolactin appears valid since dilutions of plasma and crude pituitary extract are parallel to the ovine prolactin standard and the assay is precise. The high percentage recovery of both ovine prolactin standard and marmoset pituitary prolactin added to marmoset plasma, together with the absence of plasma interference when prolactin levels are suppressed below the detection limit of the assay, clearly indicate that marmoset plasma does not show any non-specific interference in the assay. Although purified marmoset pituitary hormone preparations are not available, it is reasonable to presume that the assay is measuring prolactin since: (1) injection of bromocriptine, a specific inhibitor of prolactin secretion (Flückiger, 1972), suppressed plasma levels of prolactin; (2) TRH caused a significant rise in prolactin similar in time course to that seen in other species (Bowers, Friesen, Hwang, Guyda \& Folkers, 1971; Davis \& Borger, 1972; Convey, Tucker, Smith \& Zolman, 1972); (3) metoclopramide, a dopamine receptor antagonist, caused a highly significant increase in prolactin levels similar to the specific rise in serum levels of prolactin seen in man (McNeilly, Thorner, Volans \& Besser, 1974); and (4) injection of LH-RH, which results in a large increase in circulating levels of LH in the marmoset (Hodges, 1978), did not affect the plasma concentrations of prolactin. It is felt that the radioimmunoassay has been adequately validated to allow measurement of prolactin in the plasma of the common marmoset.

No consistent changes in plasma levels of prolactin were seen in the follicular or the luteal phase of the cycle in the marmoset. This observation is similar to those for other primates (rhesus monkey: Butler, Krey, Lu, Peckham \& Knobil, 1975; chimpanzee: Reyes, Winter, Faiman \& Hobson, 1975; gorilla: Nadler, Graham, Collins \& Gould, 1979; man: McNeilly \& Chard, 1974). It remains to be determined whether prolactin plays any role in the normal cycle of the common marmoset.

Lactation in the marmoset was associated with elevated plasma concentrations of prolactin similar to those in the rhesus monkey (Butler et al., 1975) and in women (Rolland, Lequin, Schellekens \& de Jong, 1975), but unlike the responses of these primates, suckling and its associated hyperprolactinaemia in marmosets were not associated with any delay in the return to ovulation post partum. Similarly, the luteal phase associated with first ovulation was of normal duration and progesterone levels were normal. The first post-partum cycle was also capable of leading to a pregnancy unlike the situation in breast-feeding women in which luteal function after first ovulation is usually inadequate (Delvoye, Badawi, Demaegd \& Robyn, 1978; McNeilly, 1979, 1980; Duchen \& McNeilly, 1980; McNeilly, Howie \& Houston, 1981). In this particular study, the time to conception was delayed in lactating marmosets (Table 1). Nevertheless, whether conception occurred in the first or second cycles post partum appeared to be a random event since 3 marmosets suckling twins conceived at the first ovulatory cycle. Considering birth intervals in the colony as a whole $(n=250)$, lactation per se does not influence the time of resumption of ovulatory cycles or conception post partum (Lunn \& McNeilly, 1981).

The reason for the differences in the pattern of return of fertility in lactating marmosets compared to other primates is uncertain. Primates with a long period of infant dependancy on the mother and who are immature at birth, e.g. man, chimpanzee and gorilla, have long lactation-induced birth intervals (Short, 1980). In the marmoset gestation is relatively long for such a small mammal, the young are well developed at birth, grow rapidly and are relatively independent of the mother by the time the next young are born, approximately 160 days later (Lunn \& McNeilly, 1981). It appears therefore that the marmoset has no need of a lactationinduced delay in the resumption of fertility. Nevertheless, the present results clearly show that high levels of prolactin and a maintained suckling stimulus are associated with lactation in the marmoset, and that the animal is not susceptible to the inhibitory influences of these stimuli on reproductive function, a feature unique in primates studied so far.

We thank NIAMDD for gifts of hormones; Dr J. Sandow (Hoechst) for LH-RH and TRH 
and Professor E. Flückiger (Sandoz) for bromocriptine; Miss B. Archibald, Mr M. Hulme and Miss C. Perry for prolactin and progesterone assays; Mr F. J. Burden for care and maintenance of the animals; and Professor R. V. Short for advice and encouragement.

\section{References}

Abbott, D.H. \& Hearn, J.P. (1978) Physical, hormonal and behavioural aspects of sexual development in the marmoset monkey, Callithrix jacchus. J. Reprod. Fert. 53, 155-166.

Attmann, J., Attmann, S.A. \& Hausfater, G. (1978) Primate infants effects on mothers future reproduction. Science, N.Y. 201, 1028-1030.

Bowers, C.Y., Friesen, H.G., Hwang, P., Guyda, H.J. \& Folkers, K. (1971) Prolactin and thyrotropin release in man by synthetic pyroglutamyl-histadylprolinamide. Biochem. Biophys. Res. Commun. 45, 1033-1035.

Butler, W.R., Krey, L.C., Lu, K.-H., Peckham, W.D. \& Knobil, E. (1975) Surgical disconnection of the medial basal hypothalamus and pituitary function in the rhesus monkey. IV. Prolactin secretion. Endocrinology 96, 1099-1105.

Chambers, P.C. \& Hearn, J.P. (1979) Peripheral plasma levels of progesterone, oestradiol-17 $\beta$, oestrone, testosterone, androstenedione and chorionic gonadotrophin during pregnancy in the marmoset monkey, Callithrix jacchus. J. Reprod. Fert. 56, 23-32.

Convey, E.M., Tucker, H.A., Smith, V.G. \& Zolman, J. (1972) Prolactin, thyroxine and corticoid after TRH. J. Anim. Sci. 35, 258.

Davis, S.L. \& Borger, M.L. (1972) Prolactin secretion stimulated by TRH. J. Anim. Sci. 35, 239-240.

Delvoye, P., Badawi, M., Demaegd, M. \& Robyn, C. (1978) Long lasting lactation is associated with hyperprolactinaemia and amenorrhoea. In Progress in Prolactin Physiology and Pathology, pp. 213-232. Eds C. Robyn \& M. Harter. Elsevier-North Holland-Biochemical Press, Amsterdam.

Duchen, M. \& McNeilly, A.S. (1980) Hyperprolactinaemia and long term lactational amenorrhoea. Clin. Endocr. 12, 621-627.

Fliickiger, E. (1972) Drugs and the control of prolactin secretion. In Prolactin and Carcinogenesis, pp. 167-172. Eds A. R. Boyn \& K. Griffiths. Alpha Omega Alpha, Cardiff.

Harcourt, A.H., Fossey, D., Stewart, K.J. \& Watts, D.P. (1980) Reproduction by wild gorilla and some comparisons with the chimpanzee. J. Reprod. Fert., Suppl. 28, 59-70.

Hearn, J.P. (1977) A restraining device for small monkeys. Lab. Anim. 11, 261-262.

Hearn, J.P. \& Lunn, S.F. (1975) The reproductive biology of the marmoset monkey, Callithrix jacchus. Lab. Anim. Handbook 6, 191-202.

Hearn, J.P., Lunn, S.F., Burden, F.J. \& Pilcher, M.M. (1975) Management of marmosets for biomedical research. Lab. Anim. 9, 125-134.

Hodges, J.K. (1978) Effects of gonadectomy and oestradiol treatment on plasma luteinizing hormone concentrations in the marmoset monkey. $J$. Endocr. 76, 271-281.

Lunn, S.F. \& Hearn, J.P. (1978) Breeding marmosets for medical research. In Recent Advances in Primatology; Vol. 2 Conservation, pp. 183-185. Eds D. J. Chivers \& W. Lane Petter. Academic Press, London.

Lunn, S. F. \& McNeilly, A.S. (1981) Failure of lactation to have a consistent effect on interval in the common marmoset Callithrix jacchus jacchus. Folia primatol. (in press).

McNeilly, A.S. (1979) Effects of lactation on fertility. Br. med. Bull. 35, 151-154.

McNeilly, A.S. (1980) Prolactin and the control of gonadotrophin secretion. J. Reprod. Fert. 58, 537549.

McNeilly, A.S. \& Chard, T. (1974) Circulating levels of prolactin during the menstrual cycle. Clin. Endocr. 3 , $105-112$.

McNeilly, A.S. \& Friesen, H.G. (1978) Heterologous radioimmunoassay for rabbit prolactin. Endocrinology 102, 1539-1547.

McNeilly, A.S., Thorner, M.O., Volans, G. \& Besser, G.M. (1974) Metoclopramide and prolactin. Br. med. $J .4,729$.

McNeilly, A.S., Howie, P.W. \& Houston, M.J. (1981) Relationship between feeding patterns, prolactin and the resumption of ovulation post partum. In Research Frontiers in Fertility Regulation, pp. 102-116. Eds G. I. Zatuchni, M. H. Labbok \& J. J. Sciarra. Harper \& Row, Mexico City.

Nadler, R.D., Graham, C.E., Collins, D.C. \& Gould, K.G. (1979) Plasma gonadotrophins, prolactin, gonadal steroids and genital swelling during the menstrual cycle of Lowland Gorillas. Endocrinology 105, 290-296.

Reyes, F.I., Winter, J.S.D., Faiman, C. \& Hobson, W.C. (1975) Serial serum levels of gonadotrophins, prolactin and sex steroids in the non-pregnant and pregnant chimpanzee. Endocrinology 96, 1447-1455.

Rolland, R., Lequin, R.M., Schellekens, L.A. \& de Jong, F.H. (1975) The role of prolactin in restoration of ovarian function during the early post-partum period in the human female. I. A study during physiological lactation. Clin. Endocr. 4, 15-25.

Short, R.V. (1980) The great apes of Africa. J. Reprod. Fert., Suppl. 28, 3-11.

Tutin, C.E.G. (1980) Reproductive behaviour of wild chimpanzees in the Gombe National Park, Tanzania. J. Reprod. Fert., Suppl. 28, 43-57.

Weiss, G., Dierschke, D.J., Karsch, F.J., Hotchkiss, J., Butler, W.R. \& Knobil, E. (1973) The influence of lactation on luteal function in the Rhesus monkey. Endocrinology 93, 954-959. 